\title{
DEVELOPMENT OF RADIOCARBON DATING IN CHINA OVER THE PAST 50 YEARS
}

\author{
Weijian Zhou ${ }^{1,2} \bullet$ Maobai Chen ${ }^{1,3}$
}

ABSTRACT. On the arrival of the 50th anniversary of Radiocarbon, we review important developments in radiocarbon dating in China during the past 50 years, especially concerning 3 aspects: sample standard and preparation, accelerator mass spectrometry (AMS) facilities, and ${ }^{14} \mathrm{C}$ applications. Specifically, these events are marked by the establishment of the Chinese sucrose charcoal standard in China; the development of small-sample dating in the Xi' an Laboratory of Loess and Quaternary Geology, Chinese Academy of Sciences (CAS); the progress of the AMS facilities in Beijing (China Institute of Atomic Energy and Beijing University); the innovation of the mini-cyclotron-based AMS at Shanghai Institute of Nuclear Research, CAS; the exploration of the Xia-Shang-Zhou chronology project in China; the establishment of the Xi' an multi-element AMS at the Xi' an-AMS Center; and the breakthrough in tracing the geomagnetic intensities and precipitation from ${ }^{10} \mathrm{Be}$ in Chinese loess at the Institute of Earth Environment, CAS.

\section{INTRODUCTION}

A landmark in the history of radiocarbon dating in China was established in late 1965 with the dating of the first 4 samples using the ${ }^{14} \mathrm{C}$ method (Qiu and Cai 1962, 1972; Rudolph 1973). Since then, ${ }^{14} \mathrm{C}$ dating in China has developed rapidly and has acquired many important results. Some long-lasting unresolved academic difficulties in archaeology, such as Xia-Shang-Zhou chronology, have achieved their expected outcome in the first phase of dating. The ${ }^{14} \mathrm{C}$ results in geology have provided time bases for various geological fields over the past $50 \mathrm{kyr}$, including geological event comparison, sea-level and seashore changes, land-form growth, and paleoclimate change. For example, the systematic study on abrupt climate change of the East Asia Monsoon and its instability over the past $13 \mathrm{kyr}$ has presented several new points of view (Zhou et al. 1992, 1996, 1997, 1999a,b, 2001, 2002, 2005). ${ }^{14} \mathrm{C}$ dating has thus been increasingly applied by Chinese historians and geologists.

In the 1970s, about 40 institutions engaged in work related to ${ }^{14} \mathrm{C}$ dating, with nearly 20 of these institutions establishing their own ${ }^{14} \mathrm{C}$ laboratories. As the number of ${ }^{14} \mathrm{C}$ laboratories increased, and to facilitate intercomparison and exchange among the labs, Chinese scientists decided in the winter of 1975 to establish the nationally agreed carbon standard - the Chinese sucrose charcoal standard (Qiu et al. 1982).

Before the 1990s, when China could not afford to have an AMS facility, most ${ }^{14} \mathrm{C}$ dating work in China was carried out either domestically by conventional liquid scintillation counting (LSC) or by sending samples to overseas laboratories for accelerator mass spectrometry (AMS) measurement. Therefore, the development of the small-sample (100-250 mg) device at Xi' an in the early 1990s overcame the difficult problem of small-sample dating in archaeology and geology (Zhou et al. 1994, 1995).

Owing to the scarcity of ${ }^{14} \mathrm{C}$ AMS facilities in China and the high cost of a conventional tandembased AMS, the Shanghai mini-cyclotron-based AMS (SMCAMS) project was initiated in 1985. After $13 \mathrm{yr}$ of persistent effort, the first ${ }^{14} \mathrm{C}$ result was obtained in 1993 and the first real sample was

\footnotetext{
${ }^{1}$ State Key Laboratory of Loess and Quaternary Geology, Institute of Earth Environment, Chinese Academy of Sciences, No. 10 Fenghui South Road, Hi-tech zone, Xi'an 710075, China.

${ }^{2}$ Xi' an AMS Center of IEECAS and Xi'an Jiaotong University, No. 99 Yanxiang Road, Xian 710052, China. Also: Xi'an Jiaotong University, No. 28, Xianning West Road, Xi'an 710049, China. Corresponding author. Email: weijian@loess.llqg.ac.cn.

${ }^{3}$ Shanghai Institute of Applied Physics, Chinese Academy of Sciences, Jia-Luo Road 2019, Shanghai 201800, China.
}

(C) 2009 by the Arizona Board of Regents on behalf of the University of Arizona Celebrating 50 Years of Radiocarbon

RADIOCARBON, Vol 51, $\mathrm{Nr} 1,2009$, p 91-107 
measured in 1998, which showed the "revival of the cyclotron AMS" as commented by G Raisbeck in his closing speech at the 6th International Accelerator Mass Spectrometry Conference (AMS-6).

The first AMS facility in China was the 13MV tandem AMS at the China Institute of Atomic Energy (Beijing). This is a part-time (only $\sim 10 \%$ ) AMS facility and its terminal voltage is too high to be used for ${ }^{14} \mathrm{C}$ dating. The second AMS facility in Beijing University is too busy to meet the domestic ${ }^{14} \mathrm{C}$-dating measurement demands. The third AMS facility, in Shanghai, is an experimental device more suitable for biomedical applications. Furthermore, all 3 AMS facilities are located in eastern China, and no routine ${ }^{10} \mathrm{Be}$ measurement was available. It was thus necessary to build a new AMS facility in western China. A new 3MV Tandetron-based multi-element $\left({ }^{10} \mathrm{Be},{ }^{14} \mathrm{C},{ }^{26} \mathrm{Al}\right.$, and $\left.{ }^{129} \mathrm{I}\right)$ AMS facility was then imported in 2006 at the Xi' an-AMS Center. In the meantime, a 0.6MV NECmade compact AMS was imported at Beijing University and a project to import a 6MV AMS has been planned at the China Institute of Atomic Energy.

While the ${ }^{14} \mathrm{C}$ dating methods were being developed in China, trace research was also being carried out using ${ }^{10} \mathrm{Be}$ in Chinese loess. Early on, the published research was exclusively concerned with paleoclimate. Within the last few years, however, authors have been engaging in tracing the geomagnetic intensities from ${ }^{10} \mathrm{Be}$ in Chinese loess. Some new ideas and methods were put forward, and the first geomagnetic intensity curve was derived from loess ${ }^{10} \mathrm{Be}$ for the past $80 \mathrm{kyr}$, which is in good agreement with the SINT-200 and NAPIS 75 curves.

On the arrival of the 50th anniversary of Radiocarbon, we, in this paper, discuss several important events in the development of ${ }^{14} \mathrm{C}$ dating in China during the past $50 \mathrm{yr}$, concerning 3 aspects: sample standard and preparation, AMS facilities and ${ }^{14} \mathrm{C}$ applications, as well as loess ${ }^{10} \mathrm{Be}$ trace research.

\section{ESTABLISHMENT OF THE CHINESE SUCROSE CHARCOAL STANDARD IN CHINA}

As the number of ${ }^{14} \mathrm{C}$ laboratories increased and the ${ }^{14} \mathrm{C}$ dating application fields extended, and to improve the accuracy of ${ }^{14} \mathrm{C}$ dating and the convenience of exchange and intercomparison among Chinese labs, scientists decided to establish the nationally agreed carbon standard, for which the Archaeology Institute of the Chinese Academy of the Social Sciences, the History Department of Beijing University, and the Guiyang Institute of the Earth Chemistry, Chinese Academy of Sciences were responsible. In September 1981, the "Chinese sucrose charcoal standard" was accepted at the first Chinese National ${ }^{14} \mathrm{C}$ Conference (Qiu et al. 1982, 1983).

In order to determine the ideal material for the standard, charcoal, nut carbon, filter paper, and cellulose powder were tested. Finally, pure carbonized sucrose (sugar carbon) was selected as the standard matter. About $1000 \mathrm{~kg}$ of sucrose refined from raw sugar beets harvested in 1977 were bought, the analytic reagent sucrose was extracted, and the pure sugar was carbonized (Qiu et al. 1982, 1983). No volatile matter remained in the pure sugar. The weight ratio of their burned residue (dust powder) was $<1 \%$, so the influence of radioactivity from the dust powder was lowered to a negligible level (Qiu et al. 1982, 1983). The adsorptive surface of the pure sugar was measured for the specific surface, resulting in $\sim 60 \mathrm{~m}^{2} / \mathrm{g}$, a little bigger than for the conventional matter. Such an adsorption can be removed by vacuuming under heating before burning; thus, the Chinese sugar carbon standard will not be affected by the radioactivity from the adsorbed gases (Qiu et al. 1982, 1983).

In order to precisely calibrate the ${ }^{14} \mathrm{C}$-specific radioactivity of the Chinese sucrose charcoal standard, wood (1847-1854), NBS oxalic acid, and ANU sucrose were chosen as standards. All samples were prepared in the same laboratory and adopted identical chemistry procedures in order to decrease the fractionation. The ${ }^{13} \mathrm{C}$ was measured for each sample, which was used to correct the fractionation for the measured ${ }^{14} \mathrm{C}$-specific radioactivity (Qiu et al. 1982, 1983). The measured ${ }^{13} \mathrm{C}$ 
of the sugar carbon is $19.32 \pm 0.56 \%$ relative to the international PDB standard, and the measured ${ }^{14} \mathrm{C}$-specific radioactivity of the sugar carbon is $\bar{R}=1.362 \pm 0.002$ relative to the international modern carbon standard (Qiu et al. 1982, 1983). Table 1 lists the results of the Chinese sucrose charcoal standard measured in the 3 responsible laboratories (Qiu et al. 1982).

Table 1 Results of Chinese sucrose charcoal standard measurements in the 3 responsible laboratories (the Archaeology Institute, Chinese Academy of Social Sciences (CASS); the History Department of Beijing University; and the Guiyang Institute of Earth Chemistry, Chinese Academy of Sciences (CAS). This table was originally given in Qiu et al. (1982).

\begin{tabular}{llll}
\hline & $\begin{array}{l}\text { Measured Chinese } \\
\text { sucrose charcoal } \\
\text { standard (average) }\end{array}$ & $\begin{array}{l}\text { Measured interna- } \\
\text { tional modern carbon } \\
\text { standard (average) }\end{array}$ & $\begin{array}{l}\text { Sugar carbon/ } \\
\text { modern carbon }\end{array}$ \\
\hline $\begin{array}{l}\text { Archaeology Institute of the CASS } \\
\text { (1st measurement) }\end{array}$ & $12.227 \pm 0.030$ & $8.985 \pm 0.017$ & $1.3608 \pm 0.0042$ \\
$\begin{array}{l}\text { (2nd measurement) } \\
\text { (3rd measurement) }\end{array}$ & $12.562 \pm 0.017$ & $9.224 \pm 0.014$ & $1.3619 \pm 0.0028$ \\
$\begin{array}{l}\text { History Department of Beijing University } \\
\text { (1st measurement) }\end{array}$ & $9.115 \pm 0.022$ & & $1.3590 \pm 0.005$ \\
(2nd measurement) & $12.363 \pm 0.021$ & $9.077 \pm 0.010$ & $1.3620 \pm 0.0028$ \\
Guiyang Institute of Earth Chemistry, CAS & $12.709 \pm 0.028$ & $9.344 \pm 0.018$ & $1.3600 \pm 0.004$ \\
& & $10.027 \pm 0.026$ & $1.3760 \pm 0.0076$ \\
\hline
\end{tabular}

\section{SMALL-SAMPLE DATING IN XI'AN LABORATORY OF LOESS AND QUATERNARY GEOLOGY}

\section{The Small-Sample ${ }^{14} \mathrm{C}$ Dating Device}

The establishment of a relatively accurate ${ }^{14} \mathrm{C}$ chronology for the well-defined loess-paleosol sequences in northern China is an important component of any investigation of global climate change over the past 30,000 yr. The carbon content of these sediments ranges between 1 and $2 \%$. Intensive agriculture introduced a relatively high concentration of young water-soluble organic compounds, which are then adsorbed onto the clay component of the paleosols. Thus, it is advisable to subject the organic component of the paleosols to extensive pretreatment and chemical fractionation to obtain reliable ${ }^{14} \mathrm{C}$ ages (Head et al. 1989; Zhou et al. 1990, 1992). The final components for dating are usually too small for conventional liquid scintillation counting (LSC) (Polach et al. 1988). Because of the scarcity of ${ }^{14} \mathrm{C}$ AMS facilities in the 1990s in China, and the expense of obtaining AMS dates from overseas, the concept of upgrading an existing radiometric ${ }^{14} \mathrm{C}$ dating facility to handle carbon sample sizes between 25 and $250 \mathrm{mg}$ was very attractive (Polach et al. 1988).

In the early 1990s, the Xi' an Laboratory of Loess and Quaternary Geology, CAS, developed a smallsample ${ }^{14} \mathrm{C}$ dating facility (Zhou et al. 1994, 1995) consisting of a Wallac 1220 Quantulus ${ }^{\mathrm{TM}}$ liquid scintillation spectrometer. We decided that using a full-scale benzene synthesis apparatus for samples of $<250 \mathrm{mg}$ carbon decreased the efficiency of preparation and yield of benzene. Thus, we designed a miniature system based on the procedures developed at the ANU Radiocarbon Dating Research Unit (Gupta and Polach 1985). The miniature benzene synthesis apparatus also enabled us to keep possible memory effects to a minimum. This line can produce $~ 0.3-\mathrm{mL}$ benzene samples, which are then measured for ${ }^{14} \mathrm{C}$ activity using $0.3-\mathrm{mL}$ Teflon ${ }^{\circledR}$ vials developed by Wallac Oy. The counting performance of the Quantulus spectrometer using 0.3- $\mathrm{mL}$ vials was evaluated, and a potential age limit of $\sim 45,000 \mathrm{BP}$ was obtained for samples containing up to $250 \mathrm{mg}$ carbon. This method enabled us to determine the ${ }^{14} \mathrm{C}$ activity of samples containing $250 \mathrm{mg}$ carbon with acceptable precision, even though the counting is slow. This dating facility fills the gap between large-sample (2.4-6 g carbon) and microsample ( $<1 \mathrm{mg}$ carbon) handling to form a ${ }^{14} \mathrm{C}$ dating method sequence. 
To test the accuracy of the technique, a series of previously dated samples was collected from the ANU Laboratory and the Xi'an Laboratory archives. The results of the cross-check indicated that the Xi' an Laboratory small-sample facility using liquid scintillation spectrometry can produce ${ }^{14} \mathrm{C}$ ages with precision comparable to other counting techniques. Mike Barbetti, Director of the NWG Macintosh Centre for Quaternary Dating, Sydney University, commented when reviewing this work that "By establishing the technique at Xi' an Laboratory and demonstrating that it provides good quality results, the authors have made an important and worthwhile contribution to technology in radiocarbon dating."

\section{Results for the Fourth International Radiocarbon Intercomparison (FIRI)}

In 2001, the Xi' an Laboratory of Loess and Quaternary Geology took part in the Fourth International Radiocarbon Intercomparison (FIRI) study as the one of the only participants from China. To guarantee the accuracy of the results, different kinds of samples were pretreated with corresponding physical and chemical procedures (Lu and Zhou 2003). After having been cleaned and crushed, the wood samples were put into the Soxhlet unit for leaching with a mixture of chloroform and ethanol (2:1), ethanol, and distilled water. After adding the $\mathrm{NaClO}_{2}$ to oxidize the samples under the acid conditions and using $10 \% \mathrm{NaOH}$ to remove the alkaline components, the wood cellulose was extracted for dating. The residual of the modern malt plasm was crushed. We prepared twin samples for each sample: a graphite sample for AMS measurement and small samples (240 mg) for LSC. The graphite samples were measured at VERA, in Vienna (Priller et al. 2000), with a precision of $<1 \%$ for most of the samples. The small samples were measured at this laboratory using a Quantulus 1220. During measurements (30 min each), 0.3-mL Teflon vials were used and ANU sucrose and calcite were taken as the standard and background sample, respectively. For comparing the measured results with the consensus values (Table 2) (Lu and Zhou 2003), the $t$ statistic was well below 3.481 at the $95 \%$ confidence level, indicating that our results were extremely close.

Table 2 Comparison between results from the Xi'an Laboratory of Loess and Quaternary Geology and consensus values during the Fourth International Radiocarbon Intercomparison (FIRI).

\begin{tabular}{|c|c|c|c|c|c|c|}
\hline $\begin{array}{l}\text { Sample } \\
\#\end{array}$ & $\begin{array}{l}\text { Consensus } \\
\text { values }\end{array}$ & AMS & $\begin{array}{l}t \\
\text { value }\end{array}$ & LSC & $\begin{array}{l}\text { Carbon } \\
\text { quantity } \\
(\mathrm{mg})\end{array}$ & $\begin{array}{l}t \\
\text { value }\end{array}$ \\
\hline A & $45,868 \mathrm{yr}$ & $55,283 \pm 9385 \mathrm{yr}$ & 1.01 & $>40,000 \mathrm{yr}$ & 0.2438 & - \\
\hline B & $46,504 \mathrm{yr}$ & $54,854 \pm 8040 \mathrm{yr}$ & 1.08 & $>40,000 \mathrm{yr}$ & 0.2441 & - \\
\hline $\mathrm{C}$ & $18,132 \mathrm{yr}$ & $18,065 \pm 100 \mathrm{yr}$ & 0.45 & $18,610 \pm 360 \mathrm{yr}$ & 0.2131 & 1.76 \\
\hline $\mathrm{D}$ & $4510 \mathrm{yr}$ & $4472 \pm 45 \mathrm{yr}$ & 0.71 & $4510 \pm 110 \mathrm{yr}$ & 0.2429 & 0.00 \\
\hline $\mathrm{E}$ & $11,738 \mathrm{yr}$ & $11,761 \pm 80 \mathrm{yr}$ & 0.08 & $11,660 \pm 220 \mathrm{yr}$ & 0.2437 & 0.13 \\
\hline $\mathrm{F}$ & $4482 \mathrm{yr}$ & $4500 \pm 45 \mathrm{yr}$ & 0.16 & $4440 \pm 140 \mathrm{yr}$ & 0.2454 & 0.09 \\
\hline G & $110.55 \mathrm{pMC}$ & $111.46 \pm 0.51 \mathrm{pMC}$ & 3.18 & $110.27 \pm 1.45 \mathrm{pMC}$ & 0.2451 & 0.04 \\
\hline $\mathrm{H}$ & $2229 \mathrm{yr}$ & $2174 \pm 50 \mathrm{yr}$ & 1.21 & $2340 \pm 130 \mathrm{yr}$ & 0.2435 & 0.73 \\
\hline I & $4469 \mathrm{yr}$ & $4436 \pm 40 \mathrm{yr}$ & 0.68 & $4580 \pm 160 \mathrm{yr}$ & 0.2439 & 0.48 \\
\hline $\mathrm{J}$ & $110.56 \mathrm{pMC}$ & $111.25 \pm 0.49 \mathrm{pMC}$ & 1.98 & $109.83 \pm 1.45 \mathrm{pMC}$ & 0.2429 & 0.25 \\
\hline
\end{tabular}

\section{PROGRESS OF AMS FACILITIES IN BEIJING}

\section{China Institute of Atomic Energy, Beijing}

The AMS machine at the China Institute of Atomic Energy is a HI-13 tandem-based accelerator, with which the mid-heavy nuclides (including ${ }^{10} \mathrm{Be},{ }^{26} \mathrm{Al},{ }^{36} \mathrm{Cl},{ }^{64} \mathrm{Cu},{ }^{79} \mathrm{Se},{ }^{126} \mathrm{Sn}$ and ${ }^{129} \mathrm{I}$ ) have been measured (Jiang et al. 1994a,b, 1997), and applications have concentrated on the fields of geo- 
sciences, biomedical sciences, nuclear physics, and astrophysics (Jiang et al. 2000a,b). The typical parameters of the CIAE AMS used for measurements of ${ }^{10} \mathrm{Be},{ }^{26} \mathrm{Al},{ }^{36} \mathrm{Cl},{ }^{41} \mathrm{Ca},{ }^{79} \mathrm{Se}$, and ${ }^{129} \mathrm{I}$ are listed in Table 3 (Chen JE et al. 2007). Different detecting techniques have been developed along with an $\Delta \mathrm{E}-\mathrm{E}$ ionization chamber for the detection of rare nuclides and the suppression of their isotope and isobar interferences, as indicated in Table 3. Among other things, an absorber of $15.3 \mathrm{mg} /$ $\mathrm{cm}^{2} \mathrm{Ni}$ is added in front of the $\Delta \mathrm{E}$-E ionization chamber for ${ }^{10} \mathrm{Be}$ measurement; the TOF technique is adopted for isotope identification for the measurement of ${ }^{129} \mathrm{I}$; and a projectile X-ray AMS (PXAMS) system has been set up for suppression of isobar interference in ${ }^{79} \mathrm{Se}$ and ${ }^{64} \mathrm{Cu}$ measurements (He et al. 2000). The suppression factor of Br K counts is $\sim 250 \mathrm{~m}$, corresponding to a ${ }^{79} \mathrm{Se} / \mathrm{Se}$ ratio of $3.6 \times 10^{-9}$, which improved the sensitivity by more than 2 orders of magnitude compared with a single $\mathrm{Au}-\mathrm{Si}$ detector. The overall detection efficiency was $(7.0 \pm 0.4) \times 10^{4} \mathrm{~K}$ counts per ${ }^{79} \mathrm{Se}$ ion (Guo et al. 2000a,b). Measurement techniques such as a gas-filled magnet and a gas-filled time-offlight detector have also been studied (Jiang et al. 2000b). Recently, a project has been planned at CIAE to import a 6MV AMS for analyzing even heavier nuclides.

Table 3 Typical parameters of the CIAE AMS used for measurements of ${ }^{10} \mathrm{Be},{ }^{26} \mathrm{Al},{ }^{36} \mathrm{Cl},{ }^{41} \mathrm{Ca}$, ${ }^{79} \mathrm{Se}$, and ${ }^{129}$ I nuclides (Chen JE et al. 2007).

\begin{tabular}{lllll}
\hline Radioisotopes & Negative ions & $\begin{array}{l}\text { Terminal } \\
\text { voltage }(\mathrm{MV})\end{array}$ & Detection method & Sensitivity \\
\hline${ }^{10} \mathrm{Be}$ & $\mathrm{BeO}$ & 8.4 & $\begin{array}{l}\text { absorber + ionization } \\
\text { chamber }\end{array}$ & $11 \times 10^{-14}$ \\
& & & ionization chamber & $11 \times 10^{-14}$ to -15 \\
${ }^{26} \mathrm{Al}$ & $\mathrm{Al}, \mathrm{AlO}$ & 7.6 & ionization chamber & $2 \times 10^{-15}$ \\
${ }^{36} \mathrm{Cl}$ & $\mathrm{Cl}$ & 8.0 & ionization chamber & $3 \times 10^{-14}$ \\
${ }^{41} \mathrm{Ca}$ & $\mathrm{CaF}_{3}, \mathrm{CaH}_{2}$ & 8.2 & projectile X-ray & $2 \times 10^{-11}$ \\
${ }^{79} \mathrm{Se}$ & $\mathrm{Se}$ & 8.2 & TOF & $11 \times 10^{-13}$ \\
${ }^{129} \mathrm{I}$ & $\mathrm{I}$ & 8.0 & & \\
\hline
\end{tabular}

\section{Beijing University}

The AMS facility at Beijing University (PKU-AMS) is an EN tandem-based accelerator mainly for ${ }^{14} \mathrm{C},{ }^{10} \mathrm{Be}$, and ${ }^{26} \mathrm{Al}$ measurements (Chen JE et al. 1994). It was the only routine ${ }^{14} \mathrm{C}$ measurement facility for quite a long time in China. Since 1996, it has been upgraded to meet the requirements of the Xia-Shang-Zhou Chronology Project (Guo et al. 2000a,b; Liu et al. 2000; Chen JE et al. 2007). A new ion source, MC-SNICS, from NEC was installed, the injection system was reconstructed, and the alignment and vacuum of the beam line was improved on the PKUAMS, all of which led to a precision of $0.5 \%$ in the ${ }^{14} \mathrm{C} /{ }^{13} \mathrm{C}$ ratio measurement, with a background corresponding to a ${ }^{14} \mathrm{C}$ age of $50 \mathrm{kyr}$, and an increase of the total transmission efficiency by 100\% (Li et al. 2000; Li 2002). This facility played an important role in the completion of the Xia-Shang-Zhou Chronology Project.

In 2004, a NEC-manufactured compact AMS facility (Figure 1) was imported at Peking University (Liu KX et al. 2007; Chen JE et al. 2007). This AMS facility dedicated to ${ }^{14} \mathrm{C}$ measurements is a Pelletron-type accelerator with a maximum terminal voltage of $0.6 \mathrm{MV}$ and a NEC 40-sample multicathode SNICS ion source. The tested precision and reproducibility of the facility are better than $0.3 \%$ for modern samples and the machine background is $4 \times 10^{-16}$, corresponding to a ${ }^{14} \mathrm{C}$ age of $65 \mathrm{kyr}$. Under a terminal voltage of $0.46 \mathrm{MV}$, an ion beam transmission of $43 \%$ has been reached. Since it is expected that this facility is capable of measuring 3000 samples per year, the original EN tandem-based AMS facility is now mainly used for measurements of ${ }^{10} \mathrm{Be}$ and heavier nuclides. 


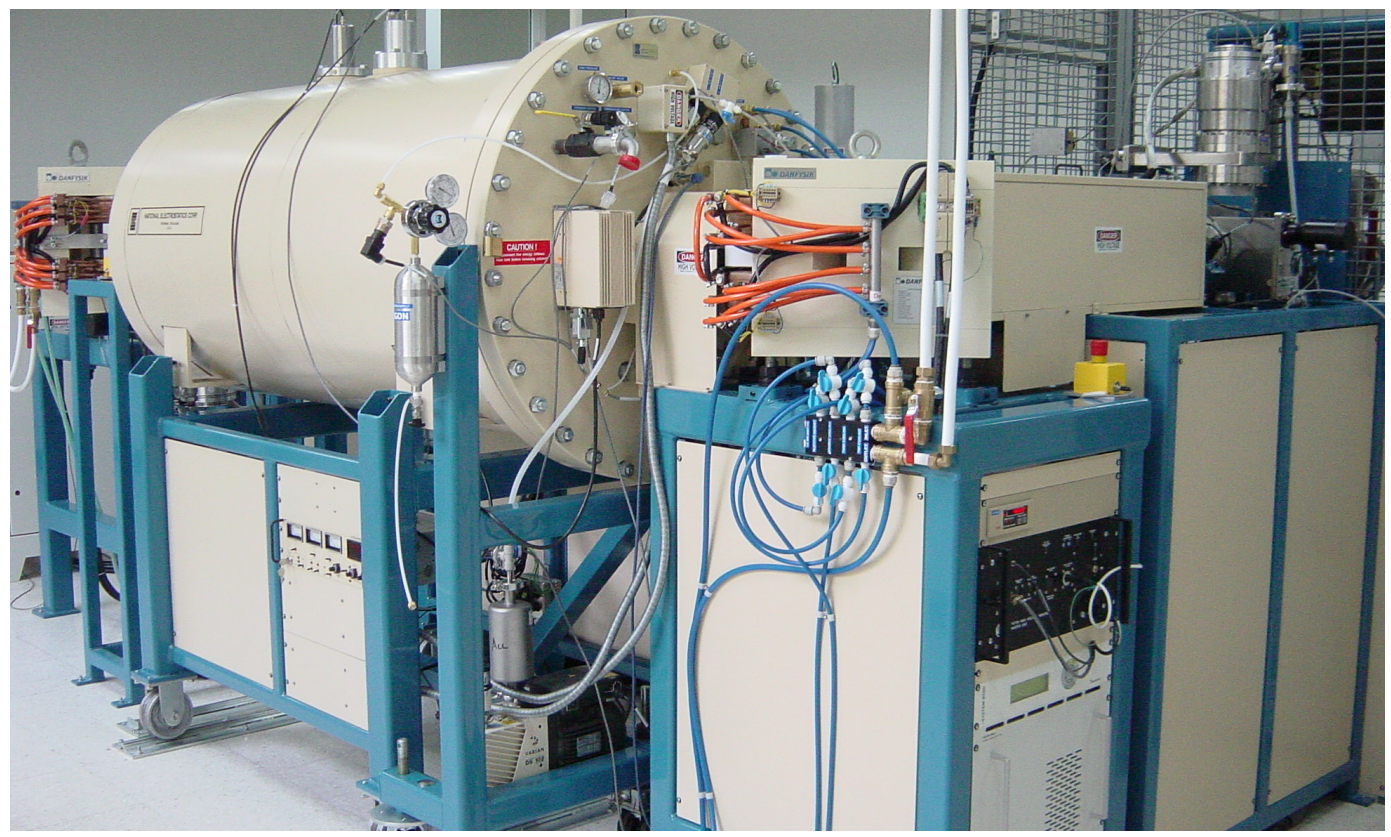

Figure 1 Photo of the compact AMS at Beijing University

\section{THE MINI-CYCLOTRON-BASED AMS AT THE SHANGHAI INSTITUTE OF NUCLEAR RESEARCH, CAS}

\section{The SMCAMS Project}

Since the early appearance of AMS, the AMS community has always been looking forward to small, even very small AMS facilities, because the existing tandem-based AMS machines were too sophisticated and expensive to be in widespread use.

In the 1950s, there was a fever to build small cyclotron mass spectrometers. However, all of them failed to get an abundance sensitivity greater than $10^{-9}$ due to their trivial beam intensity (Clark 1984). After the re-introduction of the cyclotron AMS in 1977, a small cyclotron by the name "Cyclotrino" with a uniform magnet was initiated by the R A Muller group at Berkeley. Unfortunately, the Cyclotrino, after having been explored for 2 versions (Bertsch 1987; Friedman 1987; Welch 1987), failed to achieve acceptable ${ }^{14} \mathrm{C}$ counting. It was said that the Cyclotrino had been moved to another laboratory of Berkeley for its third version, called CMS with a uniform permanent magnet (Young et al. 1993), on which no further report was seen.

Following the initiative of the Berkeley group, the mini-cyclotron with a non-uniform magnet was also submitted by the Maobai Chen group at Shanghai Institute of Nuclear Research, CAS, in late 1985 (Chen MB et al. 1987). After careful calculation and analysis, it was realized that the mini cyclotron as AMS could by no means be treated just as a conventional cyclotron, and a series of new ideas and unique technical measures were put forward (Chen MB et al. 1989a,b, 1990, 1995, 1996). The project SMCAMS (Shanghai Mini-Cyclotron-Based Accelerator Mass Spectrometer) was funded by the NSF of China and supported by the Chinese Academy of Sciences as a key project in early 1989. On 5 March 1993 , the first ${ }^{14} \mathrm{C}$ counting for a modern sample was successfully obtained at the new facility (Chen MB et al. 1994). It was not until 1998 that the first real ${ }^{14} \mathrm{C}$ measurements were carried out (Chen MB et al. 2000), which comprised 7 archaeological samples some 2000- 
$3000 \mathrm{yr}$ old and 2 geological samples that were nearly 30,000 yr old. An intercomparison of the measured results with results from the University of Arizona AMS and Beijing University AMS showed agreement within 1 to $2 \sigma$ (Zhou et al. 2000). The ${ }^{14} \mathrm{C}$ counting rates for the standard samples made from Chinese sugar (1.36 times modern carbon) reached 20-25 cps on the mini-cyclotron AMS. This was really a breakthrough for small cyclotrons as AMS after have been explored for more than 1 decade (Figure 2). The technical measures that guaranteed the success of the SMCAMS are summarized in Table 4.

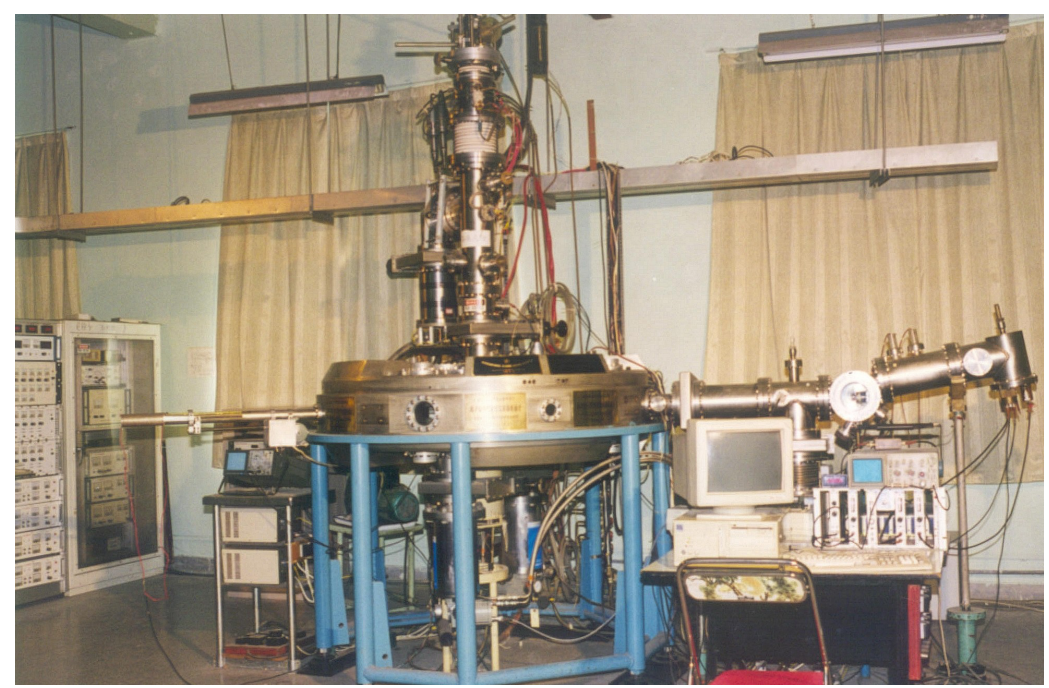

Figure 2 Photo of the Shanghai mini-cyclotron-based accelerator mass spectrometer (SMCAMS).

Table 4 Adopted technical measures that have guaranteed the success of the SMCAMS.

(1) Adopting triangle wave acceleration voltage, rather than the usual sine wave voltage, for improving the particle acceptance of the mini-cyclotron under a high harmonic operation;

(2) Constituting the differential dee electrodes with wedge shapes, rather than the usual dee dummy dee electrodes, for suitability of operation with high harmonic and for elimination of the phase convergence and divergence effect on particles;

(3) Introducing the auxiliary electrodes and asymmetric electrodes with "T" and "I" shape varying in width for obtaining the particle turn spacing wide enough and the least particle phase convergence or divergence during injection and extraction;

(4) Arranging a pair of spherical electrostatic injection deflectors, rather than the usual "mirror" or "spiral inflector," for increasing the axial injection efficiency;

(5) Designing a non-uniform magnet with high flutter and without trim coils, rather than a uniform magnet, for providing enough axial focusing and simplifying the axial injection;

(6) Keeping the constant magnetic field while controlling the electrical parameters for sequential acceleration;

(7) Choosing the larger magnet with low magnetic field, rather than the small magnet with high magnetic field, for enlarging the extraction turn spacing and setting the prohibitive zone to thoroughly suppress the background particles;

(8) Combining the yoke of nickel-coated magnet with the acceleration vacuum chamber for simplicity;

(9) Programming the ions to be analyzed around the equilibrium phase for fully making use of the powerful function of the triangular wave voltage;

(10) Making up the dynode-microchannel plate detector, rather than the usual nuclear detector, for a low counting rate of low-energy radioisotope ions;

(11) Also equipping the Cs sputter negative ion source with a multisample device for lowering the resolution demand and sequential measurement. 


\section{Status of the SMCAMS}

The SMCAMS facility keeps the advantages of both tandem- and cyclotron-based AMS. It possesses the capability of accelerating negative ions as in a tandem AMS. Furthermore, the negative ions can be directly extracted for measurement without the need of stripping. Hence, SMCAMS is the first negative heavy ion cyclotron in the world. If necessary, positive ions can also be analyzed. It also retains the function of resonance analysis of a cyclotron AMS. Moreover, the alternate acceleration can be carried out for dating applications without the need of changing the magnetic field; and primarily, it can be set up at any dating laboratory for utilitarian applications because of its low cost and operation charge, and with no expenditure of money for shielding or special buildings as a result of its small size, low energy $(50 \mathrm{keV})$, low magnetic field $(4 \mathrm{kG})$, and low power consumption $(12 \mathrm{~kW})$. Therefore, it was possible for such a mini-cyclotron AMS to achieve widespread use.

After the announcement of the successful SMCAMS results at the AMS-6 conference in 1993, there was a rush starting from 1994 to build compact tandem AMS with 0.5 to $1 \mathrm{MV}$ worldwide (Hughey et al. 1997; Mous et al. 1997; Suter et al. 1997). When SMCAMS made its first appearance, its advantage over the existing tandem-based AMS was its compact size and low cost for bioscience applications. However, after the success of the compact tandem-based AMS in the following years, the advantages of SMCAMS no longer exist. In addition, the main disadvantage of cyclotron-based AMS over tandem-based AMS is its non-flat top transmission due to the existence of the injection and extraction deflectors with narrow gaps in SMCAMS. Thus, it is impossible to make SMCAMS a commercial product, and the accelerator designers have had to use this existing SMCAMS by themselves for biomedical applications.

Since the completion of the SMCAMS in 1998, several hundred samples relating to archaeology, geology, and biomedicine have been measured on it with a measured precision around 1-3\%. If the sample preparation system had been available in this laboratory, more samples would be measured on it. Some upgrades to the facility have been completed in the past years, including new pneumatic 24-cathode structures in the Cs sputter negative ion source, a new RS-485 bus-based control system, and a new sample pressing device (Liu YH et al. 2005). In order to extend the function of the SMCAMS, which is dedicated to ${ }^{14} \mathrm{C}$ analysis at present, to ${ }^{26} \mathrm{Al}$ analysis for biomedicine applications under the existing conditions, the possibility has been studied (Wang SL et al. 2007), of which the parameters including the turn number, harmonic number, and RF frequency were determined. The orbit programming and beam optics were calculated and the pretests to accelerate ions with mass numbers of 24, 25, 26, and 27 were carried out. Finally, the $\mathrm{Al}_{2} \mathrm{O}_{3}$ sample with an isotope ratio of $1.0 \times 10^{-10}$ was measured (Wang SL et al. 2008). The ${ }^{26} \mathrm{Al}^{-}$ions were detected and its frequency response curve shows the peak of ${ }^{26} \mathrm{Al}^{-}$, though very weak, is well separated from the most neighboring interfering molecular ions, ${ }^{25} \mathrm{MgH}^{-}$.

\section{THE XIA-SHANG-ZHOU CHRONOLOGY PROJECT}

Chinese ancient civilization and its independent origin is one of 4 famous civilizations in human history, and has been lasting for nearly $5000 \mathrm{yr}$ uninterrupted. However, the Chinese ancient chronology was established just after $841 \mathrm{BC}$ and the Xia-Shang-Zhou dynasties, which have a special position in Chinese ancient history but yet have never been well confirmed by historians, which is really a pity for research of Chinese ancient history, and for world ancient history (Li et al. 2000; Li 2002).

In May 1996, the Xia-Shang-Zhou Chronology Project was commissioned in China as a national project. The Xia-Shang-Zhou Chronology Project is a multidisciplinary research program; its ultimate goal is to determine with an identifiable absolute chronology the location and time frame of the 
Xia, Shang, and Western Zhou, the 3 earliest dynasties in Chinese history (Li et al. 2000; Li 2002). The Chronology Project has involved the collaboration of more than 200 specialists in the fields of archaeology, history, astronomy, and ${ }^{14} \mathrm{C}$ dating from about 30 institutes and universities. Prof Qiu $\mathrm{SH}$, from the Archaeology Institute of the Chinese Academy of the Social Sciences, was one of the chief investigators of the project. Some 44 topics organized under 9 themes, each with explicit, realizable goals, were set up to implement the Chronology Project. After more than $4 \mathrm{yr}$ of studies, a new chronological chart of the Three Dynasties was derived and disseminated in the autumn of 2000 (Li et al. 2000; Li 2002). The new chart offers the exact reigns of 9 late Shang kings and 10 Western Zhou kings, and a framework for the chronology of the early Shang and Xia. Some important data points of the chronology are the beginning of Xia and that of Shang are dated to 2070 BC and $\sim 1600 \mathrm{BC}$, respectively; the date King Pan Geng moved the Shang capital to Yin is estimated to be $\sim 1300 \mathrm{BC}$; and the Zhou conquest of the Shang (i.e. the beginning of the Zhou Dynasty) is set at $1046 \mathrm{BC}$ ( $\mathrm{Li}$ et al. 2000). The project results were released in November 2000, completing the preset objective and paving the way for the further study of the origin of the Chinese civilization ( $\mathrm{Li}$ et al. 2000; Li 2002).

The project correlated ${ }^{14} \mathrm{C}$ dating, archaeological dating methods, historical textual analysis, astronomy, and other interdisciplinary methods to achieve more greater temporal and geographic accuracy. Selecting of sequential (serial) samples and using LSC and AMS methods for ${ }^{14} \mathrm{C}$ dating, combined with wiggle matching of the tree rings, played an important role in the timescale calibration (Li et al. 2000; Li 2002). To meet the project's requirements for high-precision ${ }^{14} \mathrm{C}$ measurement, special research on the sample preparation and measurement methods were carried out and an upgrade of the existing PKUAMS facility was done from 1996 to 1998 (Guo et al. 2000a,b; Liu et al. 2000; Chen et al. 2007). Pretreatment procedures for the wood and bone samples were determined, which improved the sample preparation efficiency. Meanwhile, existing procedures to pretreat bone materials using filtration were implemented, and it was decided to use the gluten ingredients of bone materials for ${ }^{14} \mathrm{C}$ dating ( $\mathrm{Li}$ et al. 2000; $\mathrm{Li}$ 2002). During the project, intercomparisons among different laboratories were repeatedly carried out using LSC and AMS methods for the various sequential samples from different areas over different periods, including the IAEA standard samples. The results agreed well within the error range ( $\mathrm{Li}$ et al. 2000; Li 2002).

\section{THE XI'AN MULTI-ELEMENT AMS AT THE XI'AN-AMS CENTER}

\section{The Xi'an AMS Center}

With the support of the Chinese Ministry of Science and Technology, Chinese Academy of Sciences, and Chinese Ministry of Education, the Xi'an-AMS Center was formally established in July 2006, by the Institute of Earth Environment of the Chinese Academy of Sciences and Xi'an Jiaotong University. Its main equipment is a $3 \mathrm{MV}$ Tandetron-based multi-element AMS manufactured by HVEE (Figure 3). This new AMS Center is located on the Sci-Tech campus of Xi' an Jiaotong University, in southeastern Xi'an City. The facility housing, including an accelerator hall, utility rooms, and a 3 -story sample preparation lab and office building, has a total floor space of $2500 \mathrm{~m}^{2}$. As an AMS lab in western China, we plan to measure ${ }^{10} \mathrm{Be}$ and ${ }^{14} \mathrm{C}$ in the near term, and expand the analytical work to include ${ }^{26} \mathrm{Al},{ }^{129} \mathrm{I}$, and possibly others (such as ${ }^{41} \mathrm{Ca}$ ) in the future. It is expected that the new facility will provide an important service to domestic and overseas researchers in earth environmental studies, archaeology, biomedical research, and possibly other fields (Zhou et al. 2007a,b). 


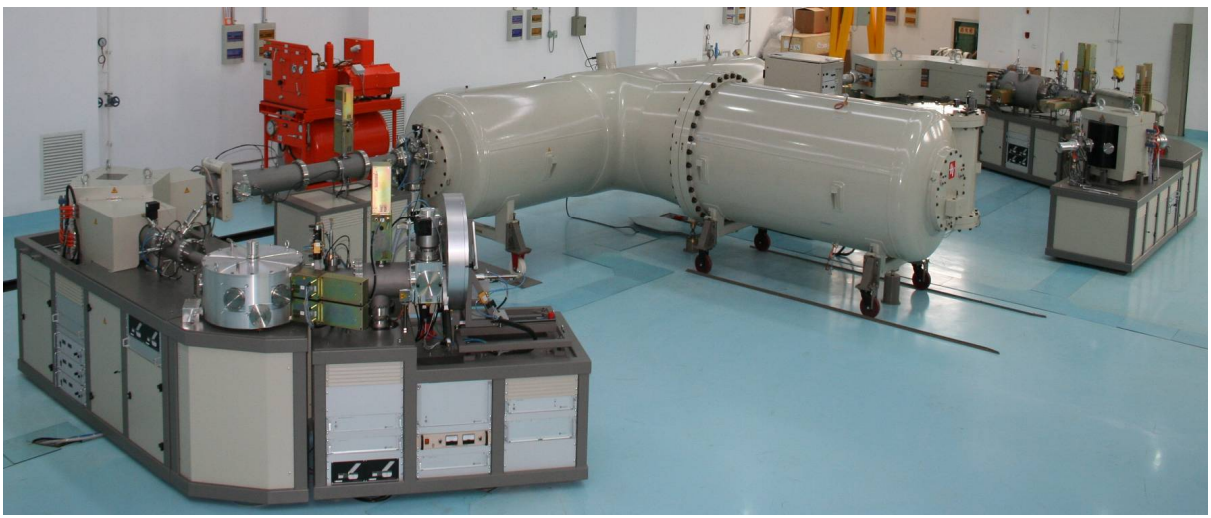

Figure 3 Photo of the Xi' an 3MV multi-element AMS (Xi'an-AMS Center)

\section{Status of the Xi'an-AMS Center}

The AMS at the Xi' an-AMS Center is the fourth version of similar products using the bouncer technique (Gottdang and Mous 1997, 1999). Along with the 3 preceding systems at JAERI (Aramaki et al. 2000), Lecce (Calcagnile et al. 2004), and INFN (Mando, personal communication, 2004), this facility is a multi-element system with a single beam line dedicated to AMS applications. The major components of the Xi' an AMS are given in Table 1 of Zhou et al. (2006). The important features are listed in Table 5 (Mous et al. 1995, 1998; Gottdang and Mous 1997, 1999; Klein et al. 2004).

Table 5 Important technical features of the Xi' an multi-element AMS facility.

(1) Ion source with grounded body makes for safe operation and easy maintenance;

(2) Sequential injection system with fast cycling of $100 \mathrm{~Hz}$ minimizes the effect of changes in the system status, like ion source instabilities;

(3) Beam blanking unit can precisely define the measuring time for different isotope ions;

(4) Q-snout makes it possible to use low-energy injection of $35 \mathrm{keV}$;

(5) Accelerator tubes with combined magnetic permanent and declined electrostatic field suppression of secondary electrons result in a very low X-ray radiation level outside the tank during operation;

(6) Slit stabilization device automatically adjusts the terminal voltage to precisely position and measure the stable isotope ions in the Faraday cup;

(7) An exceptionally uniform $\mathrm{Si}_{3} \mathrm{~N}_{4}$ foil realizes a near complete removal of ${ }^{10} \mathrm{~B}$;

(8) The high dispersion of the $65^{\circ}$ electrostatic analyzer separates the isobar ${ }^{10} \mathrm{~B}^{+3}$ ions far from the ${ }^{10} \mathrm{Be}^{+3}$ ions $(\sim 3.6 \mathrm{~cm})$ so as not to enter the detector;

(9) The $30^{\circ}$ magnet improves the precision of ${ }^{14} \mathrm{C}$ and the minimum measurable sensitivity of other isotopes;

(10) The high quality of the "flat top" transmission is shown by the good scan curves.

The Xi'an-AMS facility was installed in June 2005 and completed its final acceptance tests for 4 nuclides $\left({ }^{10} \mathrm{Be},{ }^{14} \mathrm{C},{ }^{26} \mathrm{Al}\right.$, and $\left.{ }^{129} \mathrm{I}\right)$ in July 2006 . The general results of 4 nuclides during the acceptance tests have been shown in Table 1 of previous papers (Zhou et al. 2007a,b). The acceptance tests have proven that a sequential injection-based AMS can reach the same high ${ }^{14} \mathrm{C}$ precision as a simultaneous injection-based AMS (Liu L et al. 2007). The resulting background of $3.65 \times 10^{-15}$ for the ${ }^{10} \mathrm{Be} /{ }^{9} \mathrm{Be}$ ratio is comparable to that obtained by Raisbeck et al. (1987), which once again convinced the AMS community that high measurable ${ }^{10} \mathrm{Be}$ sensitivity can also be reached on an AMS with a terminal voltage lower than $3 \mathrm{MV}$. 
While the Xi' an-AMS Center was being constructed, ${ }^{14} \mathrm{C},{ }^{10} \mathrm{Be}$, and ${ }^{129} \mathrm{I}$ sample preparation systems were designed and have now been established by the Center's scientists and engineers (Zhou et al. 2007b). Samples from ice cores $\left({ }^{10} \mathrm{Be}\right)$, meteorites $\left({ }^{10} \mathrm{Be},{ }^{26} \mathrm{Al}\right)$, bare rock $\left({ }^{10} \mathrm{Be},{ }^{26} \mathrm{Al}\right)$, and loess $\left({ }^{10} \mathrm{Be}\right)$ were prepared and measured. The background of the $\mathrm{BeO}$ reached $1.7 \times 10^{-14}$, while the measured precision of the ${ }^{129} \mathrm{I}$ was $1-1.6 \%$. Based on the existing $\mathrm{Zn}$-based ${ }^{14} \mathrm{C}$ preparation system, a new $\mathrm{H}_{2} /$ Fe-based system was built, with an output of 8-16 samples per day. About 4500 samples have been measured so far on the Xi' an-AMS, with about half of the samples coming from external laboratories.

\section{BREAKTHROUGH OF TRACING THE GEOMAGNETIC INTENSITIES FROM ${ }^{10} \mathrm{Be}$ IN CHINESE LOESS AT THE INSTITUTE OF EARTH ENVIRONMENT, CAS}

\section{${ }^{10} \mathrm{Be}$ in Tracing Geomagnetic Intensities}

Production rates of cosmogenic nuclides play a key role in their geophysical applications to tracing geomagnetic field intensities, because the shielding effect of the geomagnetic field that deflects the incident cosmic particles produces a strong correlation between geomagnetic intensity and the atmospheric cosmogenic nuclide production rate (Finkel and Suter 1993; Frank et al. 1997; Lal 1988; McHargue et al. 2000). Unlike the sedimentary ${ }^{14} \mathrm{C}$ isotope, which has shorter half-life and continuously exchanges with the atmosphere reservoir, the sedimentary ${ }^{10} \mathrm{Be}$ isotope is not retransferred into the atmosphere and can cover a longer period of time. Hence, the knowledge of past variations in ${ }^{10} \mathrm{Be}$ production rates is especially important for tracing paleogeomagnetic intensities. Numerous studies tracing the paleogeomagnetic field have shown that the ${ }^{10} \mathrm{Be}$ records from marine sediments and ice cores do generally reveal the effect of this geomagnetic modulation (Raisbeck et al. 1987; Guyodo and Valet 1996; Frank et al. 1997; McHargue et al. 2000). However, the ${ }^{10} \mathrm{Be}$ records in loess do not reflect such an effect at all due to the complexity of the origin and accumulation process of ${ }^{10} \mathrm{Be}$ in loess (Figure 4) (Shen et al. 1989; Zhou et al. 2007c,d). As a result, published studies on ${ }^{10} \mathrm{Be}$ records in loess had been exclusively concerned with paleoclimate research (Beer et al. 1993; Heller et al. 1993; Guo et al. 1996; Shen et al. 2000), where the effects of the ${ }^{10}$ Be production rate in relation to the paleogeomagnetic field were not addressed.

Since 1) there is not a generally accepted record of paleogeomagnetic intensities available at present from either marine or ice records (Frank et al. 1997); 2) the wind-blown loess sequence in China is regarded as one of the most complete terrestrial records for paleoenvironmental studies (Pan et al. 2001), due to the fact that sedimentary ${ }^{10} \mathrm{Be}$ in loess spanned an entire Quaternary interval, much wider than those in marine sediments and ice cores; and 3) there are considerable uncertainties regarding the B/M polarity conversion ( $780 \mathrm{kyr}$ ) (Zhu et al. 1994, 1998), the advantages of sedimentary loess ${ }^{10} \mathrm{Be}$ records might provide a new insight into clarifying the issue. Thus, the Weijian Zhou group at the Institute of Earth Environment, CAS, has been tracing the geomagnetic excursion events and paleointensities from high-resolution Chinese loess ${ }^{10} \mathrm{Be}$ records in order to prove that loess is able to reliably record the behavior of Earth's magnetic field.

\section{Innovative Approach to Trace Geomagnetic Intensities from ${ }^{10} \mathrm{Be}$ in Loess}

Based on the high similarity between the ${ }^{10} \mathrm{Be}$ concentration curve and the magnetic susceptibility curve measured from the Luochuan loess in China during the past $80 \mathrm{kyr}$ (Wu 2004), the author proposed an idea to separate the climate effect from the geomagnetic effect on the measured loess ${ }^{10} \mathrm{Be}$ record in order to trace paleogeomagnetic events by using the susceptibility as a proxy of ${ }^{10} \mathrm{Be}$ composition affected by climate factors (Zhou et al. 2007c). After sequentially investigating 3 analytical methods for the separation (Zhou et al. 2007c,d; Xian 2007; Xian et al. 2008), and especially with the discovery of the "mean value concept" in a monolinear regression of multivariable geological 


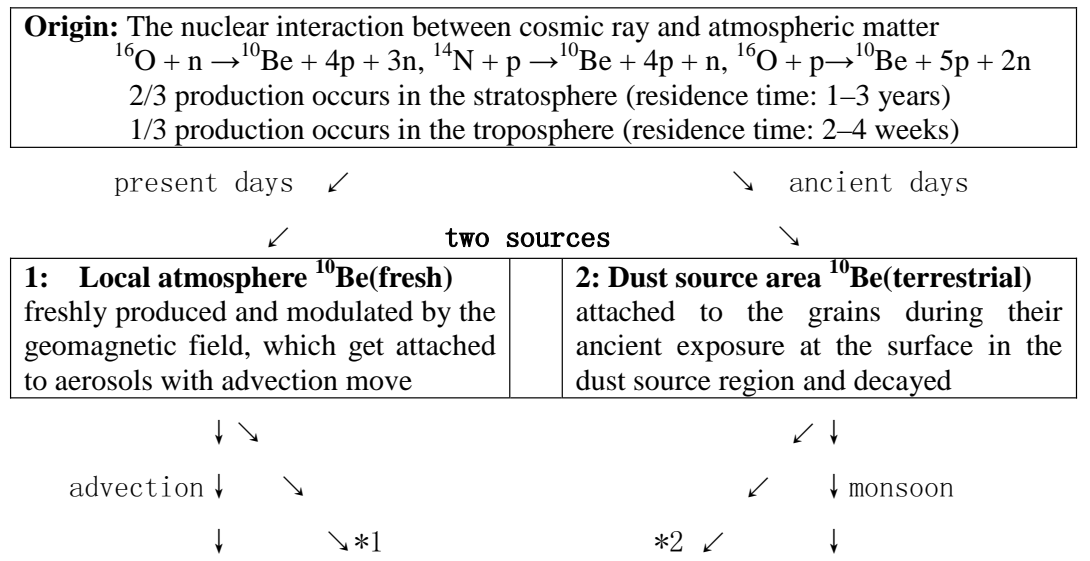

Three components in the local stratosphere where climate occurs

\begin{tabular}{|c|c|c|}
\hline $\begin{array}{l}\text { Component } 1:{ }^{10} \mathbf{B e} \text { (fresh) } \\
\text { (residence } \leqq 1 \text { month) } \\
\text { In water droplet, liquid } \\
\text { aerosols, ice crystals. } \\
*^{1} \quad \text { Encounters to } \\
\text { water-insoluble aerosols } \\
\text { with } 1 / 6 \text { of theoretical } \\
\text { probability. }\end{array}$ & $\begin{array}{c}\text { Components } 3:{ }^{10} \mathbf{B e} \text { (recycled) } \\
\text { (floating some years) } \\
\text { Dust grain of fine size with } \\
\text { decayed }{ }^{10} \mathrm{Be}(\text { terrestrial); } \\
\text { Water-insoluble aerosol with } \\
\text { freshly produced }{ }^{10} \mathrm{Be} \text { (fresh) }\end{array}$ & $\begin{array}{l}\text { Component } 2:{ }^{10} \mathbf{B e} \text { (dust) } \\
\text { (soon falling on to the loess) } \\
\text { Dust grain of coarse size with } \\
\text { decayed }{ }^{10} \mathrm{Be}(\text { terrestrial). } \\
*^{2} \quad \text { The fine grains will be } \\
\text { floating in the atmosphere }\end{array}$ \\
\hline $\begin{array}{r}\quad \downarrow \rightarrow \\
\text { rain-fa }\end{array}$ & $\begin{array}{cc}\text { dry fall } & \leftarrow \downarrow \\
& \text { scavenging }\end{array}$ & $\begin{array}{c}\downarrow \\
\text { dust-fall }\end{array}$ \\
\hline $\begin{array}{l}\downarrow \\
\downarrow \quad \swarrow \\
\end{array}$ & $\searrow$ by dust fa & $\begin{array}{ll}11 & \downarrow \\
& \searrow \quad \downarrow\end{array}$ \\
\hline $\mathrm{Be}(\mathrm{P})$ & $\leftarrow$ In loess-paleosol Be $(\mathrm{M}) \rightarrow$ & $\mathrm{Be}(\mathrm{D})$ \\
\hline
\end{tabular}

Figure 4 Scheme of the complex origin and deposition of ${ }^{10} \mathrm{Be}$ in loess. This table is compiled based on previous studies (Finkel and Suter 1993; Guo et al. 1996; Baumgartner et al. 1997); the dry fall is generally 2nd order (Wallbrink and Murray 1994).

system (Zhou et al. 2007d), the author developed an integrated method (mean value concept [MVC] method) and has reconstructed the past 80 -kyr history of the ${ }^{10} \mathrm{Be}$ relative production rate in the atmosphere from the ${ }^{10} \mathrm{Be}$ record in the Chinese Luochuan loess, and subsequently, the global geomagnetic history and the loess plateau precipitation history, which, correspondingly, are in good agreement with the SINT200 (Guo et al. 1996) and NAPIS75 (Laj et al. 2000) geomagnetic intensity records (Figure 5), and the speleothem $\delta^{18} \mathrm{O}$-based records of the paleo-Asian monsoon intensity from Dongge and Hulu caves (Wang YG et al. 2001; Yuan et al. 2004) (Figure 6). Recently, the authors have extended the MVC method to reconstruct the past 130-kyr global geomagnetic intensity and loess plateau precipitation from ${ }^{10} \mathrm{Be}$ in Luochuan loess and Xifeng loess.

This is really a breakthrough in solving the problem of how to reconstruct the paleoenvironment (paleogeomagnetic intensity and paleoprecipitation) changes from the Chinese loess ${ }^{10} \mathrm{Be}$. This technique could be used to generate an extremely long record of paleoenvironmental changes, since the loess record extends back about 2.6 Myr BP, which is only slightly more than 1 half-life of ${ }^{10} \mathrm{Be}$. 


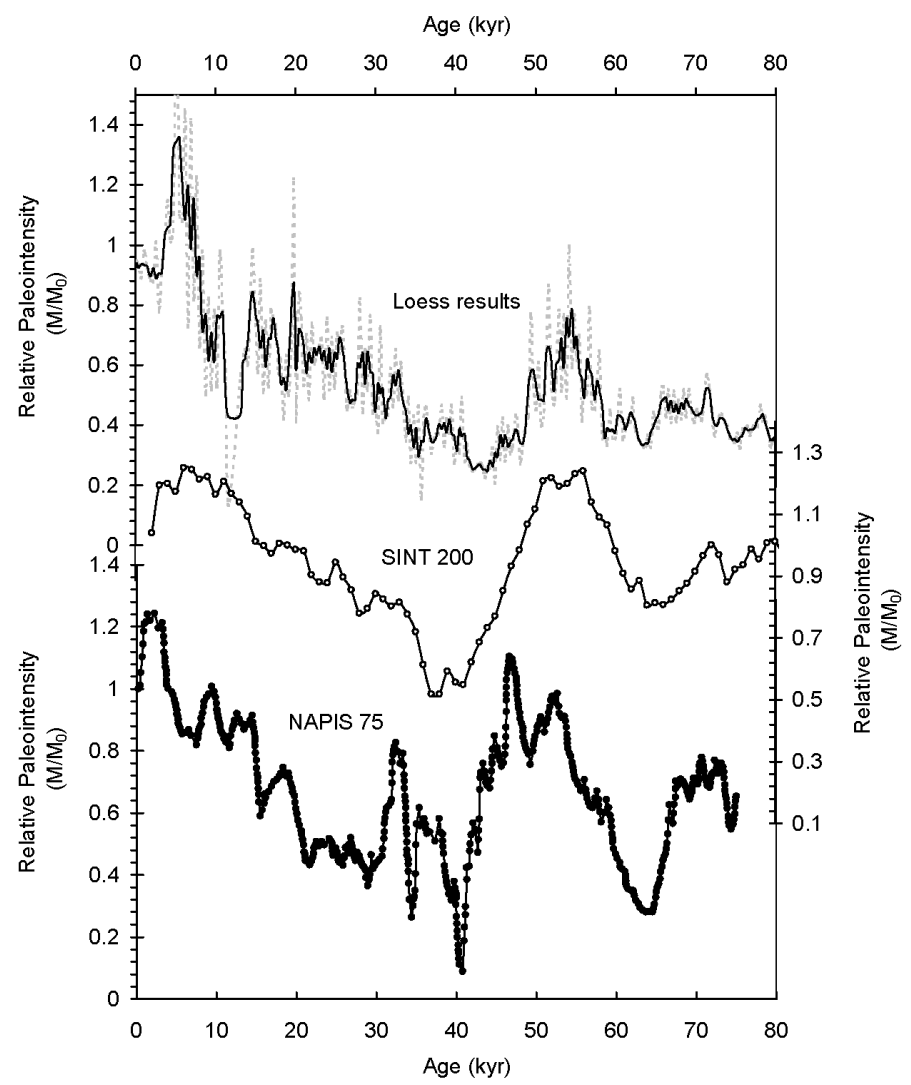

Figure 5 Curve of the first reconstructed paleogeomagnetic intensities for the past $80 \mathrm{kyr}$ from ${ }^{10} \mathrm{Be}$ in Chinese Louchuan loess and its comparison with the famous SINT-200 and NAPS75 curves.

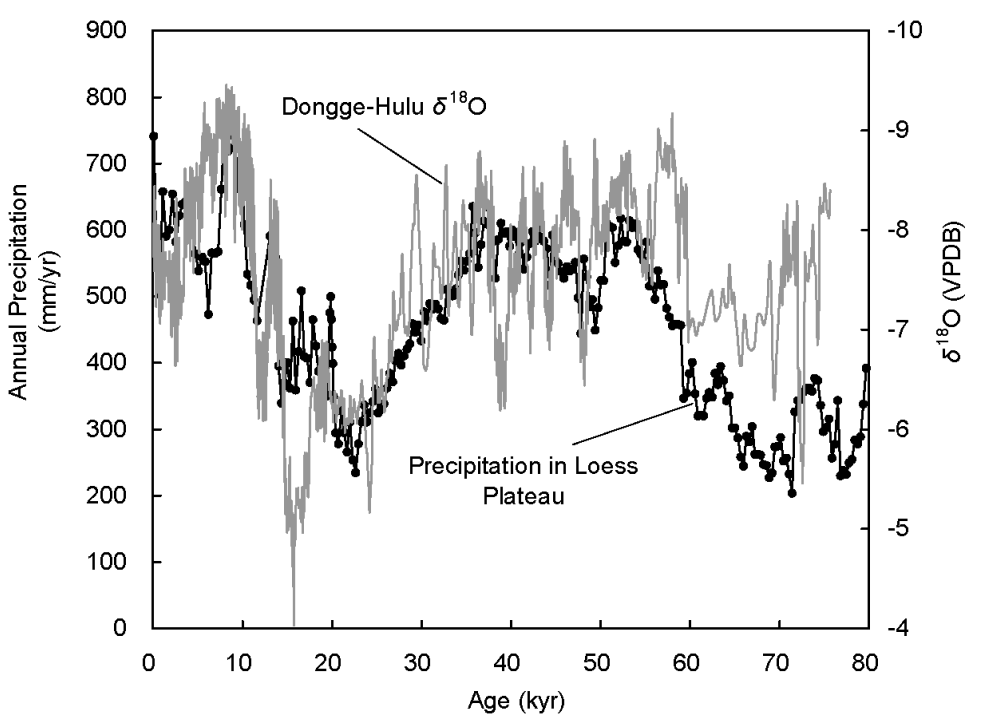

Figure 6 Curve of the reconstructed 80-kyr precipitation history over the loess plateau from ${ }^{10} \mathrm{Be}$ in Chinese Louchuan loess and its comparison with the speleothem $\delta^{18} \mathrm{O}$ based records of paleo-Asian monsoon intensity from Dongge and Hulu caves. 


\section{ACKNOWLEDGMENTS}

We would like to express our deep thanks to Profs Li XQ, Qiu SH, Chen JE, Cai LZ, Chen TM, Yuan SX, Shen CD, Jiang SS, Yang LP, Zhou MF, Guo ZY, Zhao XL, Liu ZH, Liu KX, Jiang S, Li DM, Wu XH, Zhang XL; Drs Lu XF, Wu ZK, Xian F, and Cheng P for their outstanding work and contributions in the development of ${ }^{14} \mathrm{C}$ dating and AMS in China over the past $50 \mathrm{yr}$, which have been adopted in this review. We are also indebted to Prof An ZS for his support in our work related to ${ }^{14} \mathrm{C}$ dating and AMS establishment. The authors gratefully acknowledge support for this work from the National Science Foundation of China, the Knowledge Innovation Program of the Chinese Academy of Sciences, and the National Basic Research Program of China.

\section{REFERENCES}

Aramaki T, Mizushima T, Mizutani Y, Yamamoto T, Togawa O, Kabuto S, Kuji T, Gottdang A, Klein M, Mous DJW. 2000. The AMS facility at the Japan Atomic Energy Research Institute. Nuclear Instruments and Methods in Physics Research B 172(1-4): $18-23$.

Baumgartner S, Beer J, Wagner G, Kubik P, Suter M, Raisbeck GM, Yiou F. 1997. ${ }^{10} \mathrm{Be}$ and dust. Nuclear Instruments and Methods in Physics Research B 123(1-4):296-301.

Beer J, Shen CD, Heller F, Liu TS, Bonani G, Dittrich B, Suter M, Kubik PW. 1993. ${ }^{10} \mathrm{Be}$ and magnetic susceptibility in Chinese loess. Geophysical Research Letters 20(1):57-60.

Bertsche KJ. 1987. A small low-energy cyclotron for radioisotope measurements [PhD dissertation]. Lawrence Berkeley Laboratory Report LBL-28106.

Calcagnile L, Quarta G, D'Elia M, Gottdang A, Klein M, Mous DJW. 2004. Radiocarbon precision tests at the Lecce AMS facility using a sequential injection system. Nuclear Instruments and Methods in Physics Research B 215(3-4):561-4.

Chen JE, Guo ZY, Yan SQ, Li RX, Xiao M, Li K, Liu HT, Liu KX, Wang JJ, Li B, Lu XY, Yuan S, Chen TM, Gao SJ, Zheng SH, Chen CY, Liu Y. 1994. Accelerator mass spectrometry at Peking University: experiments and progress. Nuclear Instruments and Methods in Physics Research B 92(1-4):47-50.

Chen JE, Guo ZY, Liu KX, Wu XH, Jiang S, Zhou WJ. 2007. The progress of accelerator mass spectrometry and their applications in China. In: Proceedings of the Fourth Asian Particle Accelerator Conference (APAC 2007), Indore, India: Raja Ramanna Centre for Advanced Technology (RRCAT). p 597-600.

Chen MB, Li DM, Gao WJ, Xu SM. 1987. Some peculiar features of a mini-cyclotron as a mass spectrometer for dating. In: Proceedings of the 14th International Conference on Cyclotrons and Their Applications. p 660-3.

Chen MB, Gao WZ, Li DM. 1989a. Design criteria on a minicyclotron as a mass spectrometer for dating. $\mathrm{Nu}-$ clear Instruments and Methods in Physics Research $A$ 278(2):402-8
Chen MB, Li DM, Gao WZ, Zhang XL, Zhou RF. 1989b. Adopting a non-sinusoidal wave dee voltage in minicyclotrons as mass spectrometers for dating. Nuclear Instruments and Methods in Physics Research A 278(2):409-16.

Chen MB, Xu SL, Li DM, Zhang XL, Chen GS, Gao WZ. 1990. Determination of the shape of the dee electrodes in the SINR minicyclotron used as AMS for ${ }^{14} \mathrm{C}$ dating. Nuclear Instruments and Methods in Physics Research A 297(1-2):47-59.

Chen MB, Li DM, Xu SL, Chen GS, Zhang YJ, Lu XS, Zhang WY, Zhang YX, Zhong ZK. 1994. The successful SINR mini cyclotron AMS for ${ }^{14} \mathrm{C}$ dating. Nuclear Instruments and Methods in Physics Research B 92(14):213-6.

Chen MB, Li DM, Xu SL, Chen GS, Shen LG, Lu XS, Zhang WY, Zhong ZK, Zhang YJ. 1995. Breakthrough of the mini-cyclotron mass spectrometer for ${ }^{14} \mathrm{C}$ analysis. Radiocarbon 37(2):675-81.

Chen MB, Li DM, Xu SL, Chen GS, Shen LG, Lu XS, Zhang YJ. 1996. A new type of mini-cyclotron as accelerator mass spectrometer. In: Proceedings of the 14th International Conference on Cyclotrons and Their Applications. Cape Town, South Africa, 1995. Beijing: World Scientific Publishing Co. p 107-10.

Chen MB, Lu XS, Chen GS, Xu SL, Shen LG, Li DM, Zhang YX, Gong PR, Zhang YJ, Zhou WJ. 1997. Status of the SINR mini-cyclotron AMS facility. Nuclear Instruments and Methods in Physics Research B 123(1-4):102-6.

Chen MB, Lu XS, Li DM, Liu YH, Zhou WJ, Chen GS, Shen LG, Xu SL, Zhang YX. 2000. Mini-cyclotron (SMCAMS)-based accelerator mass spectrometry and real ${ }^{14} \mathrm{C}$ measurements. Nuclear Instruments and Methods in Physics Research B 172(1-4):193-200.

Clark DJ, editor. 1984. Proceedings of the 10th International Conference on Cyclotrons and Their Applications. East Lansing, Michigan, USA: IEEE. 534 p.

Finkel RC, Suter M. 1993. AMS in the earth sciences: technique and applications. Advances in Analytical Geochemistry 1:1-114.

Frank M, Schwarz B, Baumann S, Kubik PW, Suter M, Mangini A. 1997. A $200 \mathrm{kyr}$ record of cosmogenic ra- 
dionuclide production rate and geomagnetic field intensity from ${ }^{10} \mathrm{Be}$ in globally stacked deep-sea sediments. Earth and Planetary Science Letters 149(1-4): 121-9.

Friedman PG. 1987. A low background-rate detector for ions in the 5 to $50 \mathrm{keV}$ energy range to be used for radioisotope dating with a small cyclotron $[\mathrm{PhD}$ dissertation]. Lawrence Berkeley Laboratory Report LBL17804.

Gottdang A, Mous DJW. 1997. The novel HVEE multielement AMS system. Nuclear Instruments and Methods in Physics Research B 123(1-4):163-6.

Gottdang A, Mous DJW. 1999. Characteristics of the HVEE 3MV multi-element AMS system. In: Duggan $\mathrm{JL}$, Morgan IL, editors. Proceedings of the 15th International Conference on Application of Accelerators in Research and Industry. Denton, Texas, USA, November 1998. New York: Springer Verlag. p 652-6.

Guo ZY, Lal D, Liu TS, Southon J, Caffee MW, Guo ZT, Chen MY. 1996. Five million year ${ }^{10} \mathrm{Be}$ record in Chinese loess and red-clay: climate and weathering relationships. Earth and Planetary Science Letters 144(12):273-87.

Guo ZY, Liu KX, Lu XY, Ma HG, Li K, Yuan SX, Wu XH. 2000a. The use of AMS radiocarbon dating for Xia-Shang-Zhou chronology. Nuclear Instruments and Methods in Physics Research B 172(1-4):724-31.

Guo ZY, Ma HG, Liu KX, Jiang S, Chen MB, Liu YH. 2000b. Development of accelerator mass spectrometry in China. In: Proceedings of the Second Asian Particle Accelerator Conference. 17-21 September 2001, Beijing, China. p 858-61.

Gupta SK, Polach HA. 1985. Radiocarbon Dating Practices at ANU. Canberra: Australian National University. $171 \mathrm{p}$.

Guyodo Y, Valet J-P. 1996. Relative variations in geomagnetic intensity from sedimentary records: the past 200,000 years. Earth and Planetary Science Letters 143(1-4):23-36.

He M, Jiang S, Jiang S, Chen Q, Qin J, Wu S, Dong Y, Zhao Z. 2000. Measurement of ${ }^{79} \mathrm{Se}$ and ${ }^{64} \mathrm{Cu}$ with PXAMS. Nuclear Instruments and Methods in Physics Research B 172(1-4):177-81.

Head MJ, Zhou WJ, Zhou MF. 1989. Evaluation of ${ }^{14} \mathrm{C}$ ages of organic fractions of paleosols from loess paleosol sequences near Xi'an, China. Radiocarbon 31(3):680-96.

Heller F, Shen CD, Beer J, Liu XM, Liu TS, Bronger A, Suter M, Kubik PW. 1993. Quantitative estimates of pedogenic ferromagnetic mineral formation in Chinese loess and palaeoclimatic implications. Earth and Planetary Science Letters 114(2-3):385-90.

Hughey BJ, Klinkowstein RE, Shefer RE, Skipper PL, Tannenbaum SR, Wishnok JS. 1997. Design of a compact 1MV AMS system for biomedical research. $\mathrm{Nu}$ clear Instruments and Methods in Physics Research B 123(1-4):153-8.
Jiang SS, Jiang S, Guo H, Yang BF. 1994a. Accelerator mass spectrometry at the China Institute of Atomic Energy. Nuclear Instruments and Methods in Physics Research B 92(1-4):61-4.

Jiang SS, Jiang S, Guo H, Du S, Chen Z, Guo Q, Zhao Y. 1994b. Determination of ${ }^{36} \mathrm{Cl}$ in the groundwaters and ores around a uranium deposit. Nuclear Instruments and Methods in Physics Research B 92(1-4):385-8.

Jiang SS, Guo J, Jiang S, Li CS, Cui AZ, He M, Wu SY, Li SL. 1997. Determination of the half-life of ${ }^{79} \mathrm{Se}$ with the accelerator mass spectrometry technique. $\mathrm{Nu}$ clear Instruments and Methods in Physics Research B 123(1-4):405-9.

Jiang S, He M, Jiang SS, Wu SY, Dong Y, Yang BF, Bao YW, Guo JY, Li ZC, Zhao ZX, Zhang SD, Guo JR. 2000a. Development of AMS measurements and applications at the CIAE. Nuclear Instruments and Methods in Physics Research B 172(1-4):87-90.

Jiang S, He M, Wu SY, Zhao ZX, Dong Y. 2000b. A gasfilled time-of-flight detector system and a new method for particle identification. Nuclear Instruments and Methods in Physics Research B 172(1-4):305-9.

Klein M, Mous DJW, Gottdang A. 2004. Fast and accurate sequential injection AMS with gated Faraday cup current measurement. Radiocarbon 46(1):77-82.

Laj C, Kissel C, Mazaud A, Channell JET, Beer J. 2000. North Atlantic paleointensity stack since $75 \mathrm{ka}$ (NAPIS-75) and the duration of the Laschamp event. Philosophical Transactions of the Royal Society A 358(1768):1009-25.

Lal D. 1988. Theoretically expected variations in the terrestrial cosmic-ray production rates of isotopes. In: Castagnoli DC, editor. Solar-Terrestrial Relationships and the Earth Environment in the Last Millennia. Volume XCV. Amsterdam: North Holland. p 216-33.

Li XQ. 2002. The Xia-Shang-Zhou Chronology Project: methodology and results. Journal of East Asian Archaeology 4(1-4):321-33.

Li XQ, Qiu SH, Gan SJ, Li BQ, Xi ZZ. 2000. Report on the Xia-Shang-Zhou Project Between 1996 and 2000 (compact). Beijing: World Publishing Co. p 1-11. In Chinese.

Liu KX, Guo ZY, Lu XY, Ma HJ, Li B, Wang JJ, Zhou GH, Yuan JL, Ren XT, Zhao Q, Zhang ZF, Zhang GJ, Yuan SX, Wu XH, Li K, Chen CE. 2000. Improvements of PKUAMS for precision ${ }^{14} \mathrm{C}$ analysis of the project of Xia-Shang-Zhou Chronology. Nuclear Instruments and Methods in Physics Research B 172(14):70-4.

Liu KX, Ding XF, Fu DP, Pan Y, Wu XH, Guo ZY, Zhou LP. 2007. A new compact AMS system at Peking University. Nuclear Instruments and Methods in Physics Research B 259(1):23-6.

Liu L, Zhou WJ, Cheng P, Yu HG, Chen MB. 2007. A new dual injection system for AMS facility. Nuclear Instruments and Methods in Physics Research B 259(1):208-12. 
Liu YH, Wanh SL, Li DM, Jian WH, Chen MB. 2005. The status of SMCAMS after several upgrades in the last few years [poster]. Presented at the 10th International Conference on Accelerator Mass Spectrometry, Berkeley, California, 5-10 September 2005.

Lu XF, Zhou WJ. 2003. Preliminary results for the fourth international radiocarbon intercomparison study. Geochimica 32(1):43-7. In Chinese.

McHargue LR, Donahue D, Damon PE, Sonett CP, Biddulph D, Burr G. 2000. Geomagnetic modulation of the late Pleistocene cosmic-ray flux as determined by ${ }^{10} \mathrm{Be}$ from Blake Outer Ridge marine sediments. $\mathrm{Nu}$ clear Instruments and Methods in Physics Research $B$ 172(1-4):555-61.

Mous DJW, Gottdang A, van den Broek R, Haitsma RG. 1995. Recent developments at HVEE. Nuclear Instruments and Methods in Physics Research B 99(1-4): 697-700.

Mous DJW, Purser KH, Fokker W, van den Broek R, Koopmans RB. 1997. A compact ${ }^{14} \mathrm{C}$ isotope ratio mass spectrometer for biomedical applications. $\mathrm{Nu}$ clear Instruments and Methods in Physics Research B 123(1-4):159-62.

Mous DJW, Fokker W, van den Broek R, Koopmans R, Bronk Ramsey C, Hedges REM. 1998. An ion source for the $\mathrm{HVEE}{ }^{14} \mathrm{C}$ isotope ratio mass spectrometer for biomedical applications. Radiocarbon 40(1):283-8.

Pan YX, Zhu RX, Shaw J, Liu QS, Guo B. 2001. Can relative paleointensities be determined from the normalized magnetization of the wind-blown loess of China? Journal of Geophysical Research 106(B9):19,221-32.

Polach H, Kaihola L, Robertson S, Hass H. 1988. Small sample ${ }^{14} \mathrm{C}$ dating by liquid scintillation spectrometry. Radiocarbon 30(2):153-5.

Priller A, Brandl T, Gosler R, Kutschera W, Puchegger S, Rom W, Steier P, Vockenhuber C, Wallner A, Wild E. 2000. Extension of the measuring capabilities at VERA. Nuclear Instruments and Methods in Physics Research B 172(1-4):100-6.

Qiu SH, Cai LC. 1962. The introduction of sucrose radiocarbon. K'ao Ku (Archaeology) 8:441-6. In Chinese.

Qiu SH, Cai LC. 1972. The report on radiocarbon dating. K'ao Ku (Archaeology) 1:52-6. In Chinese.

Qiu SH, Cai LZ, Xian ZQ, Bao GC, Chen TM, Yuan SX, Ma L, Shen CD, Qiao YL. 1982. Report on the Chinese sucrose charcoal standard for ${ }^{14} \mathrm{C}$ dating. Proceedings of the First National Conference on ${ }^{14} \mathrm{C}$. p 110. In Chinese.

Qiu SH, Cai LZ, Xian ZQ, Bao GC, Chen TM, Yuan SX, Ma L, Shen CD, Qiao YL. 1983. Report on the Chinese sucrose charcoal standard for ${ }^{14} \mathrm{C}$ dating. Chinese Science Bulletin 28(5):170-4.

Raisbeck GM, Yiou F, Bourles D, Lestringuez J, Deboffle D. 1987. Measurements of ${ }^{10} \mathrm{Be}$ and ${ }^{26} \mathrm{Al}$ with a tandetron AMS facility. Nuclear Instruments and Methods in Physics Research B 29(1-2):22-6.

Rudolph RC. 1973. The first carbon-14 dating in China. Isis 64(1):101-2.
Shen CD, Liu TS, Beer J, Oeschger H, Bonani G, Suter M, Wolfli W. 1989. ${ }^{10} \mathrm{Be}$ and evolution of loess accumulation. Science in China, Series B 7:744-51. In Chinese.

Shen CD, Beer J, Heller F, Kubik PW, Suter M, Liu TS. 2000. ${ }^{10} \mathrm{Be}$-susceptibility model and quantitative estimates of pedogenic ferromagnetic material flux in Chinese loess. Nuclear Instruments and Methods in Physics Research B 172(1-4):551-4.

Suter M, Jacob S, Synal H-A. 1997. AMS of ${ }^{14} \mathrm{C}$ at low energies. Nuclear Instruments and Methods in Physics Research B 123(1-4):148-52.

Wallbrink PJ, Murray AS. 1994. Fallout of ${ }^{7} \mathrm{Be}$ in south eastern Australia. Journal of Environmental Radioactivity 25(3):213-28.

Wang SL, Liu YH, Li DM, Chen MB. 2007. Progress in analyzing ${ }^{26} \mathrm{Al}$ with SMCAMS. Nuclear Techniques 30(10):1-6. In Chinese.

Wang SL, Liu YH, Li DM, Chen MB. 2008. Study of ${ }^{26} \mathrm{Al}$ measurement on the Shanghai mini-cyclotron based AMS. Nuclear Instruments and Methods in Physics Research B 266(14):3302-8.

Wang YJ, Cheng H, Edwards RL, An ZS, Wu JY, Shen CC, Dorale JA. 2001. A high-resolution absolutedated late Pleistocene monsoon record from Hulu Cave, China. Science 294(5550):2345-8.

Welch JJ. 1987. A low-energy cyclotron for radiocarbon dating [PhD dissertation]. Lawrence Berkeley Laboratory Report LBL-21255.

Wu ZK. 2004. High-resolution ${ }^{10} \mathrm{Be}$ record from the middle part of the loess plateau and reconstruction of east Asian monsoon history over the last $130 \mathrm{ka}$ [PhD dissertation]. Chinese Academy of Sciences. In Chinese.

Xian F. 2007. Study of data analysis procedure for the past $80 \mathrm{ka}$ paleogeomagnetic field tracing and paleoprecipitation reconstruction from ${ }^{10} \mathrm{Be}$ in loess of China over the last $80 \mathrm{ka}$ [PhD dissertation]. Chinese Academy of Sciences. In Chinese.

Xian F, An ZS, Wu ZK, Beck JW, Yu HG, Kang ZH, Cheng P. 2008. A simple model for reconstructing geomagnetic field intensity with ${ }^{10} \mathrm{Be}$ production rate and its application in loess studies. Science in China, Series D 51(6):855-61.

Young AT, Bertsche KJ, Clark DJ, Halbach K, Kunkel WB, Leung KN, Li CY, Rawlins A, Schlueter RD, Stuart ME, Wells RP, Yu JX. 1993. Development of a compact permanent-magnet cyclotron for accelerator mass-spectrometry. In: Proceedings of the 1993 IEEE Particle Accelerator Conference. 17-20 May 1993, Washington, DC. p 1727-9.

Yuan DX, Cheng H, Edwards RL, Dykoski CA, Kelly MJ, Zhang ML, Qing JM, Lin YS, Wang YJ, Wu JY, Dorale JA, An ZS, Cai YJ. 2004. Timing, duration, and transitions of the Last Interglacial Asian Monsoon. Science 304(5670):575-8.

Zhou WJ, Zhou MF, Head MJ. 1990. ${ }^{14} \mathrm{C}$ chronology of Bei Zhuang Cun sedimentation sequence since 30,000 years BP. Chinese Science Bulletin 35(7):567-72. 
Zhou WJ, An ZS, Lin B, Xiao JZ, Zhang J, Xie J, Zhou MF, Porter SC, Head MJ, Donahue DJ. 1992. Chronology of the Baxie loess profile and the history of monsoon climates in China between 17,000 and 6000 years BP. Radiocarbon 34(3):818-25.

Zhou WJ, Head MJ, Kaihola LR. 1994. Small sample dating in China. Radiocarbon 36(1):47-9.

Zhou WJ, Zhou MF, Yang LP. 1995. Small sample liquid scintillation counting technique for radiocarbon dating. Geochimica 24(2):146-51. In Chinese.

Zhou WJ, Donahue DJ, Porter SC, Jull AJT, Li XQ, Stuiver M, An ZS, Matsumoto EJ, Dong GR. 1996. Variability of monsoon climate in East Asia at the end of the last glaciation. Quaternary Research 46(3): 219-29.

Zhou WJ, Donahue DJ, Jull AJT. 1997. Radiocarbon AMS dating of pollen concentrated from eolian sediments: implications for monsoon climate change since the late Quaternary. Radiocarbon 39(1):19-26.

Zhou WJ, Head MJ, Lu XF, An ZS, Jull AJT, Donahue DJ. 1999a. Teleconnection of climatic events between East Asia and polar, high latitude areas during the last deglaciation. Palaeogeography, Palaeoclimatology, Palaeoecology 152(1-2):163-72.

Zhou WJ, Head MJ, Wang F, Donahue DJ, Jull AJT. 1999b. The reliability of AMS radiocarbon dating of shells from China. Radiocarbon 41(1):17-24.

Zhou WJ, Chen MB, Liu YH, Donahue D, Head J, Lu XF, Jull ATJ, Deng L. 2000. Radiocarbon determinations using a minicyclotron: application in archaeology. $\mathrm{Nu}$ clear Instruments and Methods in Physics Research B 172(1-4):201-5.

Zhou WJ, Head MJ, An ZS, De Deckker P, Liu ZY, Liu XD, Lu XF, Donahue DJ, Jull AJT, Beck WJ. 2001. Terrestrial evidence for a spatial structure of tropicalpolar interconnections during the Younger Dryas episode. Earth and Planetary Science Letters 191(3-4): 231-9.

Zhou WJ, Dodson J, Head MJ, Li BS, Hou YJ, Lu XF, Donahue DJ, Jull AJT. 2002. Environmental variabil- ity within the Chinese desert-loess transition zone over the last 20,000 years. Holocene 12(1):107-12.

Zhou WJ, Xie SC, Meyers PA, Zheng YH. 2005. Reconstruction of late glacial and Holocene climate evolution in southern China from geolipids and pollen in the Dingnan peat sequence. Organic Geochemistry 36(9): 1272-84.

Zhou WJ, Zhao XL, Lu XF, Liu L, Wu ZK, Peng C, Zhao WN, Huang CH. 2006. The 3MV multi-element AMS in Xi' an, China: unique features and preliminary tests. Radiocarbon 48(2):285-93.

Zhou WJ, Lu XF, Wu ZK, Zhao WN, Huang CH, Li LL, Cheng P, Xin ZH. 2007a. New results on Xi' an-AMS and sample preparation systems at Xi' an-AMS center. Nuclear Instruments and Methods in Physics Research B 262(1):135-42.

Zhou WJ, LU XF, Wu ZK, Zhao WN, Huang CH, Li LL, Cheng P. 2007b. The Xi'an-AMS facility at Xi'anAMS Centre. Nuclear Techniques 30(8):702-8. In Chinese.

Zhou WJ, Priller A, Beck JW, Wu ZK, Chen MB, An ZS, Kutschera W, Xian F, Yu HG, Liu L. 2007c. Disentangling geomagnetic and precipitation signals in an 80kyr Chinese loess record of ${ }^{10} \mathrm{Be}$. Radiocarbon 49(1): 139-60.

Zhou WJ, Chen MB, Xian F, Song SH, Wu ZK, Jull AJT, Liu WG. 2007d. The mean value concept in mono-linear regression of multi-variables and its application to trace studies in geosciences. Science in China, Series D 50(12):1828-34.

Zhu RX, Laj C, Mazaud A. 1994. The Matuyama-Brunhes and upper Jaramillo transitions recorded in a loess section at Weinan, north-central China. Earth and Planetary Science Letters 125(1-4):143-58.

Zhu RX, Pan YX, Guo B, Liu QS. 1998. A recording phase lag between ocean and continent climate changes: constrained by the Matuyama/Brunhes polarity boundary. Chinese Science Bulletin 43(19): 1593-9. 